\title{
Regional Resource Management Based on Landscape Ecology in Northern Muria Peninsula, Central Java
}

\author{
Joko Wiyono and Sunarto
}

Received: 24102015 / Accepted: 15012016 / Published online: 30062016

(๑) 2016 Faculty of Geography UGM and The Indonesian Geographers Association

\begin{abstract}
Landscape ecology can be used to identify potential resources based on it physical, biological and socio-cultural characteristics. This research was conducted in the northern part of the Muria Peninsula. This study uses observation and sampling based on toposequences transects. The northern Muria Peninsula is a complex area. Landscape in this region is strongly influenced by volcanism in the past of Muria Volcano and Genuk Volcano also geomorphological processes such as fluvial and marine. Potential resources in the northern part of the Muria Peninsula such as potential for marine, mining, agriculture, farming, and tourism. Muria Peninsula regional management should be adapted to the potential and function of each area, so that will not cause environmental degradation.
\end{abstract}

Keywords: Landscape, Landscape ecology, Regional resource management, Geomorphological process

\begin{abstract}
Abstrak Ekologi bentanglahan dapat digunakan untuk mengidentifikasi potensi wilayah berdasarkan karakteristik fisik, biologi dan sosial-budaya. Penelitian ini dilakukan di Semenanjung Muria bagian utara. Penelitian ini menggunakan metode pengamatan dan pengambilan sampel berdasarkan jalur transek toposekuen. Semenanjung Muria bagian utara merupakan wilayah yang kompleks. Bentanglahan yang ada di wilayah ini sangat dipengaruhi oleh aktivitas vulkanisme di masa lalu dari Gunungapi Muria dan Gunungapi Genuk serta proses geomorfologi masa kini seperti fluvial dan marin. Potensi sumberdaya yang ada di Semenanjung Muria bagian utara antara lain potensi laut, tambang, pertanian, perkebunan, dan pariwisata. Pengelolaan wilayah di Semenanjung Muria hendaknya disesuaikan dengan potensi dan fungsi dari masing-masing kawasan sehingga tidak menimbulkan degradasi lingkungan.
\end{abstract}

Kata kunci: Bentanglahan, Ekologi bentanglahan, Pengelolaan sumberdaya wilayah, Proses geomorfologi

\section{Introduction}

The concept of ecological landscapes or geoecology can be applied in various fields. This concept is widely used in inventory and resource management in countries of Europe and America. However, this concept has not been widely used in Indonesia. This concept can integrate the various components of the environment and its spatial aspects so as to provide the results of a comprehensive analysis. This concept can be used to identify potential areas based on the physical, biological and socio-cultural [Mardiatno, 2002; Sultanisah, 2007]. Management of areas with this concept can maintain ecosystem function study area. Resource management in Indonesia still partial and override environmental aspects. Therefore, it is important to do a study of landscape ecology or geoecology in Indonesia.

Landscape ecology is the study of the structure, function and dynamics on a stretch of heterogeneous containing ecosystem interactions. Landscape ecology focuses on connectivity and interaction between the forest (vegetation) in the expanse of the earth and the effects of natural and human disturbances to the landscape. Because man became one of the

Joko Wiyono and Sunarto

Faculty of Geography, Universitas Gadjah Mada, Indonesia Email: joko.wiyono@mail.ugm.ac.id dominant biology, ecology landscape much focus on the interaction between humans and the biosphere components [Forman and Godron, 1986]. Landscape ecology is a concept that connects every component in the environment both physical components, biological and human. Landscape ecology the basis for environmental studies [Fandeli and Muhammad, 2009].

Factors controlling the landscape changed in recent decades. Formerly the composition of the landscape is strongly influenced by the physical component. But with the increase of population and road network resulted in increasing landscape heterogeneity. Landscape in the world are experiencing significant changes due to the influence of social factors (economic, technological, cultural, demographic, and history) as well as biophysical factors (eg geology, soils and hydrology) [Dikou, et al, 2011].

Muria Peninsula is one area that has distinctive characteristics in Java. Muria peninsula consists of three main landscapes, there are the Volcanic Landscape, Marine, and Fluvial. Muria peninsula formed from volcanic seafloor. As a result of the appointment process, the seabed volcano becomes an island of volcanoes [Wibowo, et al, 2008]. Muria Volcano Island provides a good substrate for coral reefs. Muria volcano and volcanic Genuk been inactive though it still holds 
the potential volcanic activity [McBirney, et al, 2003]. Process developed at this time is the process of erosion by the flow of the river that forms the fluvial landscape.

Northern Muria peninsula has a type of volcanic coasts. Landscape in the northern part of the Muria Peninsula is not much affected by sedimentation processes such as in the southern part of that legacy / former process of the past can still be observed [Sunarto, 2004]. Past the former process, among others, the basaltic lava rocks, fossils of marine life and marine notch formations that can show the dynamics of sea level in the ice age and interglacial.

Northern Muria Peninsula covers an area of Muria volcano to the north coast and the island of Mandalika. Drastic changes in topography lead to differences in microclimate. Microclimate may affect the type and distribution of flora / fauna endemic. In this region there is a nature reserve and protected forest Celering Mount Muria volcano. Serves as a nature reserve conservation area flora and fauna. Most of the area was superbly turned into a nature preserve agricultural land as a result of looting [BKSDA Jateng, 2009]. Banyumanis village and Ujungwatu, Donorojo Subdistrict previously been studied and designed to be the location of the project site a nuclear power plant but opposed by residents and can not be implemented until today. This area has not been studied so not much is known characteristics. A thorough research about the resource potential can be used for decision making in the management of the area in the northern part of the Muria Peninsula.

Analysis of landscape ecology using landscape ecological unit of analysis unit. Ecological unit consisting of units landform landscape with native vegetation such landforms. Landform as a venue for interaction between environmental components play an important role. Landform conditions affect the processes and components thereon. Each unit of landscape ecology has distinct characteristics both abiotic, biotic, and socio-cultural. Somewhere landscape ecology unit is unique and can be distinguished by other units of landscape ecology. It can facilitate the planning and implementation of environmental management.

Based on this background, it can be formulated several research questions as follows:

1. What are the units of landscape ecology in northern Muria Peninsula?

2. What are the potential of each unit of landscape ecology in the northern Muria Peninsula?

Based on the formulation of the problem and the research questions above, it can be arranged research purposes. General objective of this study is to analyze the potential of the area using the concept of landscape ecology. The purpose of detailed research is divided into two, namely:

1) Assessing ecological landscape unit in northern Muria Peninsula,
2) Analyze the potential of each unit of landscape ecology in the northern part of the Muria Peninsula.

\section{The Methods}

The research was conducted in late May to early June 2015 and August 2015. The area that was chosen to be the location of the study is in the northern part of the Muria Peninsula, precisely in the Subdistrict of Keling and Donorojo, Jepara Regency and Subdistrict portion Cluwak and Dukuhseti, Pati Regency. The study area is a combination of several Watershed tipped in Muria Volcano and Volcano Genuk. Watershed who entered the study area include Gelis Watershed, Telon, Pasaran, Wangkong and Pojok. The study area includes protected forest Muria volcano, Gunung Celering Nature Reserve, and Mandalika Island.

Collection of field data conducted sampling to represent the population. The sampling technique used was purposive sampling data retrieval. Sampling technique is based on the intent and purpose of the study to be achieved. Samples were taken at points that have a diversity of ecological phenomena spans land. Sampling was done by a combination of field between the data quantitative and qualitative data. The unit of analysis used is ecological landscape unit or units geoecology. The unit of analysis is restricted based on the results of landforms and ecological data overlay.

Sampling locations are determined based on variations in the ecological characteristics of the landscape in the northern part of the Muria Peninsula. Sample points taken transect formed a transverse profile that can be observed variations in topography to the ecosystem formed (toposequences). Affordability and accessibility aspects are also taken into consideration in determining the location of the sample. Landscape conditions Northern Muria Peninsulais relatively uniform, but there are specific different locations namely Muria Volcano, Volcano Genuk and Mandalika Island. Therefore, selected transects of Muria VolcanoGenuk Volcano-Mandalika island, that can represent ecological conditions of northern Muria Peninsula overall. Stages of research can be simplified in the form of research diagram is shown in Figure 1.

\section{Result and Discussion \\ Description Muria Peninsula Northern Territory}

Muria peninsula stretches the northern part actually covers two districts, namely Jepara and Pati District and includes several districts. Districts which were included in the study include the entire District of Keling and Donorojo in Jepara district and sub-district portion Dukuhseti and Cluwak in Pati regency

Northern Muria Peninsula has a climate type B based climate classification Schmidt-Ferguson, in the category of very wet. Schmidt and Fergusson climate classification is often used as the basis of biological alama resource management (agriculture, plantation, forestry, fishery and livestock) in Indonesia. Number of 


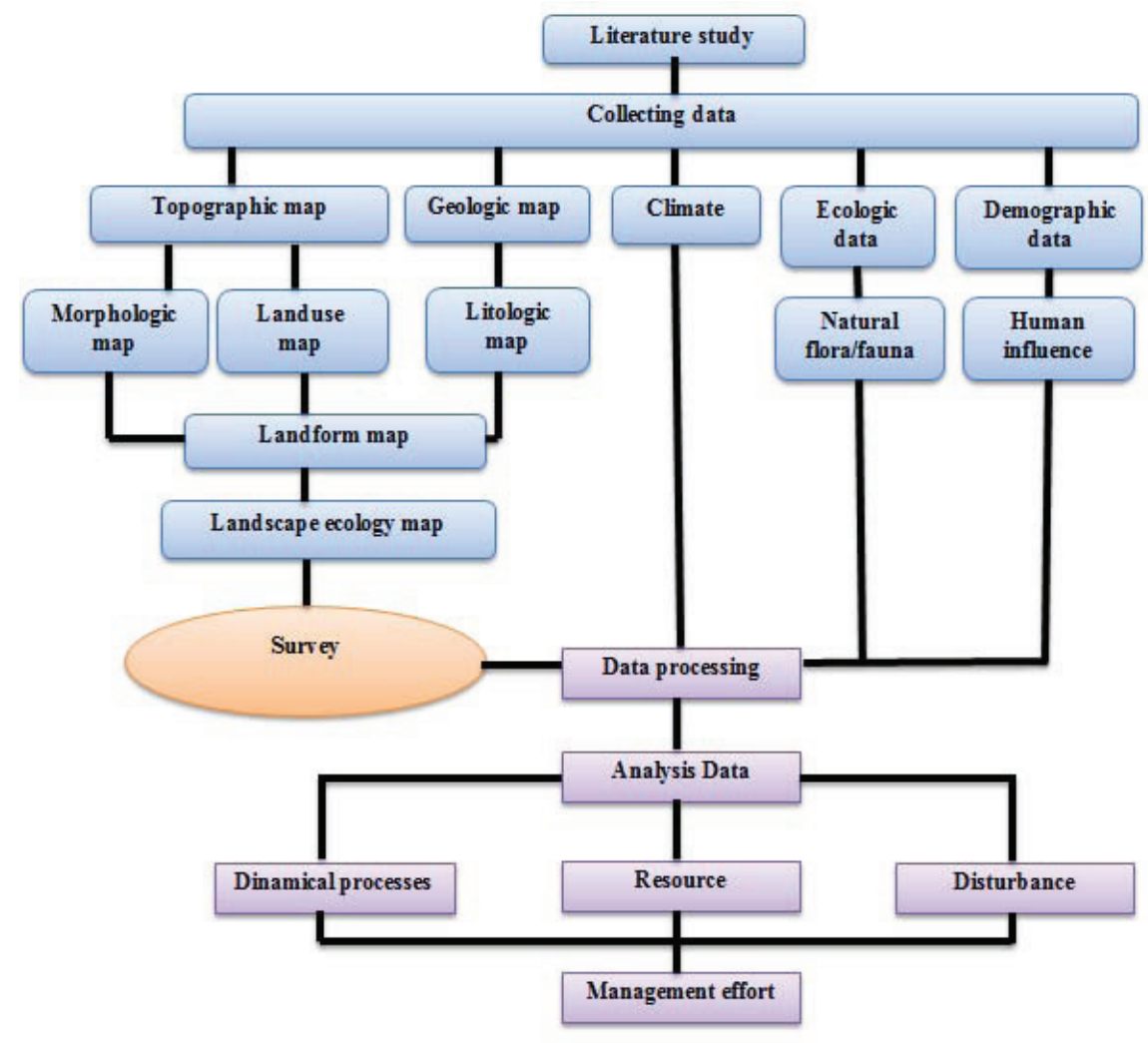

Figure 1. Flowchart of research.

wet months (rainfall $\geq 100 \mathrm{~mm}$ ) is greater than the dry months (rainfall $\leq 60 \mathrm{~mm}$ ). The rainy marineon occurs from November to April and the dry marineon lasts from May to October. The area has an average rainfall of 3,588 $\mathrm{mm}$ per year and the air temperature $18-350$ C. Northern Muria Peninsula fed by several rivers, such as the Kali Gelis, Wangkong, Telon, Pojok, and Pasaran.

Northern Muria Peninsula is part of the GenukMuria volcano system. Bedrock in this area is the result of two volcanic eruptions, namely blocks of lava, volcanic breccia, lava, tuffaceous sandstone and tuffaceous crosses. Genuk Muria volcano and is now inactive so that the dominant process is the process of denudation. Strong erosion processes that leave scars in the form of hills with steep slopes. Accumulated sediment forming the ground material. The type of soil in the northern part of the Muria Peninsula, among others andosol brown, red litosol, latosol brown, and brown regosol. Existing land use in the northern part of the Muria Peninsula among other settlements, irrigated rice, rainfed, gardens, fields, and forests. The division of ecological landscape unit Northern Muria Peninsula shown in Figure 2.

\section{Landscape Ecological Land Classification Unit Muria Peninsula Northern}

1) Shallow Marine

The shallow marine is an ecosystems in the northern part of the Muria Peninsula. The sea area is actually included in the category waterscape, not including the landscape. However, the shallow sea on the Muria Peninsula have a great relationship with the landscape on the mainland so that it can be divided into separate units of landscape ecology. Muria Peninsula shallow sea in the north is the Java Sea. Java Sea belonging to the inland sea, which means that the sea is surrounded by islands and not facing directly to the ocean. Landscape ecology unit has a shallow sea depth varies between 0-20 $\mathrm{m}$. The ocean depths belonging to the photic zone because sunlight can still reach the seabed. Distance from the beach varies, with an average distance of $2 \mathrm{~km}$.

Oceanographic conditions in shallow marine landscape ecology unit is strongly influenced by the marineons. The marineons that exist are west monsoon, transition I, east monsoon, and transition II. West monsoon occure from December to February, the first transitional marineon in March-May, east monsoon in June-August, and the second transitional marineon in September-November. In the west monsoon, the dominant wind leads to the east, in the first shift eastwards, east monsoon to the west, and the transitional marineon II eastward. Within a year of the dominant wind direction is toward the east. The movement of the wind effect on currents and waves. Currents in shallow marine can be grouped into longshore currents and current perpendicular to the coast. The movement of currents and this resulted in an erosion wave on somewhere and sedimentation elsewhere.

Shallow sea landscape ecology unit has a substrate in the form of volcanic lava rock. The rocks derived from 


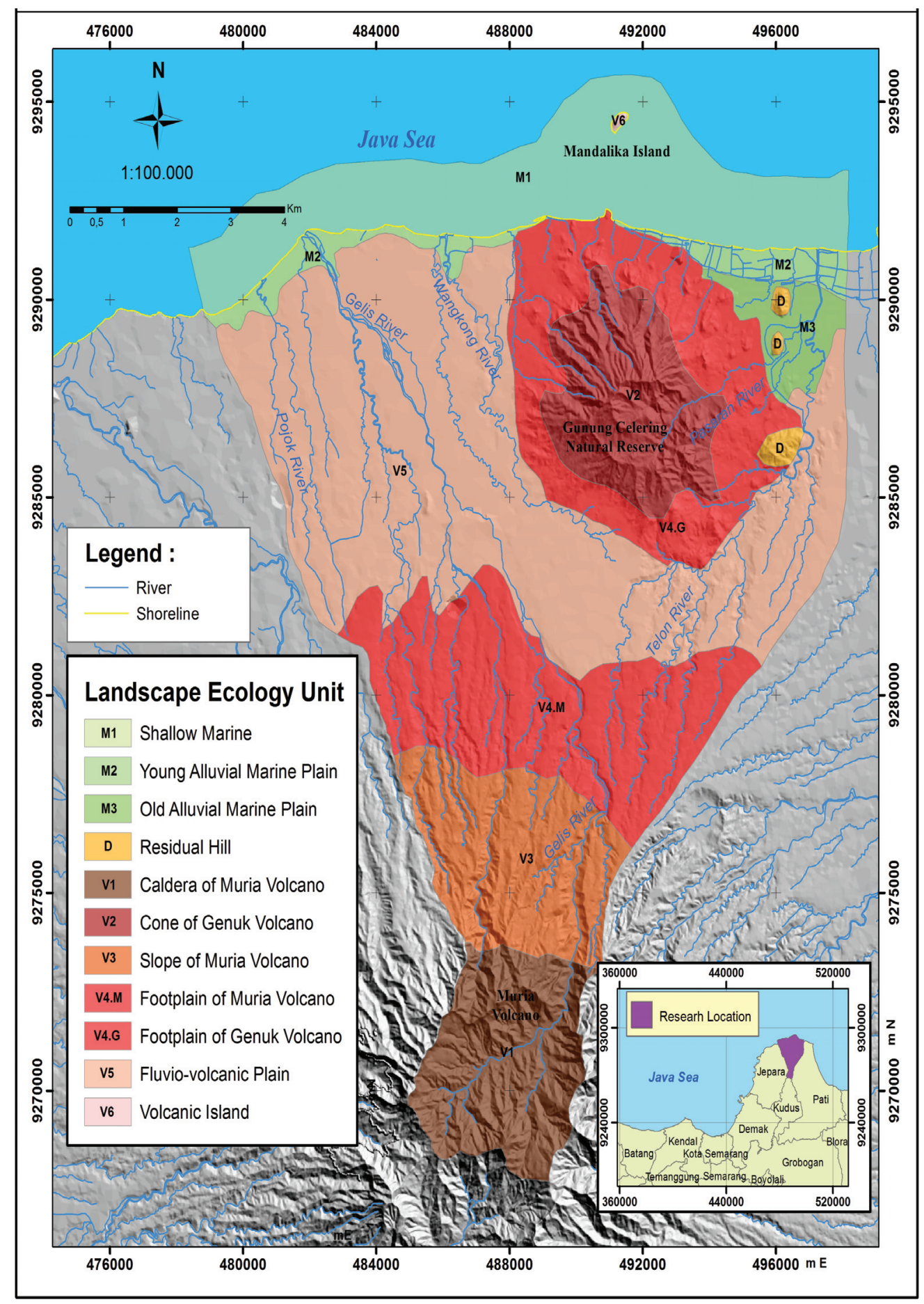

Figure 2. Northern Muria Peninsula ecological map.

volcanic eruptions in the past Genuk Volcano. Volcanic lava rock outcrop one of which can be observed in the Portuguese bastion Beach, Ujungwatu. In some places, volcanic lava rock sand sediment has covered so it does not appear again. This substrate is actually a good place for the growth and development of coral reefs. However, oceanographic factors such as strong currents and waves and sediment load is quite high causing coral reefs can not grow well in this landscape ecology unit.
Potential ecological landscape unit primarily of shallow marine resources. Fish resources in landscape ecology unit include Shrimp (Caridea), crab (Brachyura), layur fish (Trichiurus lepturus), and tuna (Euthynnus affinis). Many coastal residents utilize the potential of the marine resources to be a fisherman. Dock used as a fishing pier, among others, in addition to the Portuguese bastion, Ujung Watu and Muara Kali Telon, Tegalombo. The relationship between humans 
and the environment caused humans to read natural signs. There is local knowledge that is trusted by the people of the north coast of the Muria Peninsula. Local wisdom that is able to read a sign that there will be a storm at sea by looking at the clouds above the Genuk Volcano. If Genuk Volcano sunny then there will not be a storm at sea. Meanwhile, if there are clouds above Genuk Volcano, then certainly there will be a storm at sea so that the fishermen would be deterred for fishing.

\section{2)Volcanic Island}

Mandalika Island is a volcanic island formed from lava intrusion. Bedrock of the island is rock originating from Genuk volcanic lava. The island has a steep rocky coast. In the northern part of the island there is a little pocket beach. Coastal erosion by waves and currents is the dominant process. However, since it consists of bedrock in the form of blocks of lava, the consequences of erosion is relatively small and do not cause any harm.

Mandalika island forest is only manned by the lighthouse. In the past the island had been a settlement, but has now been abandoned. The island is currently a jungle of vegetation in the form of annual crops such as mango, jackfruit, shrubs and bushes. On this island are endemic vegetation, namely jackfruit boar. Unlike wild boar jackfruit jackfruit trees in general. Jackfruit wild boar in the soil or in the base of the tree, in contrast to the general jackfruit hanging on the rod. Jackfruit round with a wild boar taste and smell similar to jackfruit in general. Fauna on the island among other Eagle Mandalika white (Spizaetus cirrhatus), pythons (Python bivittatus) and several other snake species, as well as various species of reptiles and insects. On the island there are also Mandalika endemic fauna, namely snakes Lempe. Lempe snakes are highly venomous sea snakes. These snakes are usually located in the shallow waters near the island or carried waves to the rocky beach.

Mandalika island community wisdom in the form of myths and beliefs that developed in the surrounding community. On this island there is the tomb Ustman Sayid Al Aththos, a scholar propagator of Islam in the kingdom of Demak. This tomb is sacred by local people and became one of the pilgrimage. Pengkeramatan somewhere can become one of the environmental protection efbastions of the damage. Residents do not dare to harm the environment Mandalika island for fear of getting bad luck or supernatural beings plagued the island's caretaker.

\section{3)Young Alluvial Marine Plain}

Young alluvial marine plain is located on the East and West Genuk Volcano. The two unit of the landscape ecology have different characteristics. Landscape ecology unit in the east Volcano Genuk formed from the deposition of material carried by longshore currents. Materials such as sand and mud. In the unit there are landscape ecology estuary Telon. Telon estuary is used as a fishing pier. In the dock are the fish auction place (TPI) as well as a small market. The dominant land use in units of landscape ecology are ponds. Ponds been flat location close to the sea and to facilitate the circulation of brackish water. Type commodities developed include black tiger shrimp (Penaeus monodon), vaname shrimp (Litopenaeus vannamei) and milkfish (Chanos Chanos).

The units of landscape ecology in the west Volcano Genuk have a stronger ocean currents as well as abrasive. This causes the alluvial plains in the west marine narrower. Marine alluvial plains of the west side contains a lot of iron sand. The resulting iron sands mining process into a more intensive abrasion resulting damage and loss of population in the pond the other side of the coast. Therefore, the iron sand mining finally closed in 2014. The young marine alluvial flats to the west is planned to be the location of the project site Nuclear Power Plant. However, it is still opposed by local people so that the construction is suspended until 2017.

Marine young alluvial plains has good potential to be developed. The potential that can be developed in the alluvial plains of the east are young marine intensification of shrimp ponds and fish. In addition it should need mangrove planting on muddy coast to resist abrasion which could damage the pond. Telon estuary as fishing pier needs to be organized so as not to cause pollution and environmental damage. Potential young marine alluvial plains to the west could be developed for the cultivation of agriculture and tourism. In the unit there are landscape ecology attraction tritip Goa and the Portuguese bastion. If the nuclear power plant project implemented, it is necessary to Planning, implementation, and monitoring of good order not to cause environmental damage and conflicts with the surrounding communities.

\section{4)Old Alluvial Marine plains}

Unit ecological landscape alluvial plain old marine located in the east Volcano Genuk. The landscape ecological unit formed from sediment material by ocean currents during the days of the quarter. Material deposited material in the form of a mixture of sand and clay. Soil formed is regosol brown soil. The dominant land use on landscape ecology unit is irrigated plantations and rice fields. Commodities were developed in a rubber plantation (Hevea brasiliensis). Irrigated rice field gained from Kali Telon. Cultivated agricultural commodity is rice and pulses. Potential ecological unit alluvial plain landscape marine can be developed with the intensification of agriculture and plantation. This can increase the quality and quantity of production.

\footnotetext{
5)Foot Slopes of Genuk Volcano

Foot slope of Genuk Volcano is part of the Volcano Genuk which has undergone a process of denudation.
} 
Denudation processes of Genuk volcano cause a strong erosion and sedimentation of volcanic cones at the foot of the slopes of volcanoes. Volcano Foot slope Genuk consists of two geological formations, namely the formation Patiayam and Genuk Lava Formation. The rocks on the basis of these landforms are block lava, volcanic breccia, tuffaceous sandstones and tuffaceous conglomerate. Soil formed among others regosol chocolate on the side of the North and East, as well as red litosol on the South and West sides. Water resource potential in this landform is quite abundant. Potential water resources come from rivers that disgorge in Genuk volcanic cones and spring-springs that surround the volcanic Genuk.

Volcano Foot Genuk slopes used as agricultural land, settlements and forest. Other types of agricultural land between rice paddies and fields. Agricultural commodities in paddy fields interspersed with crops are rice (paddy 2-3 times, 1 time crops in one year). agricultural commodities on dry land are crops and cassava. Forest land is divided into two, namely forestry and forest owned forests owned by residents. Perhutani owned forests in the form of protected forests and production forests planted with kapok (Ceiba pentranda) as a producer of cotton for the textile industry. Forests owned by residents largely also planted with kapok, while other hardwoods such plants as building material.

\section{6)Cone of Genuk Volcano}

Cone of Genuk Volcano largely entered the nature reserve of Mount Celering, others entered perhutani areas and settlements. Settlements located in the former volcanic caldera Genuk. The caldera to the east. Settlements in the volcano caldera Genuk is Blingoh village settlement area and Jugo. The village can be reached by road on the slopes of Volcano Genuk South.

Genuk volcano is a dead volcano (extinct). Genuk active volcanoes is estimated between 0.84 Ma (Megaannun / million years) to about $0.49 \mathrm{Ma}$ [Wibowo, et al, 2008]. Genuk volcanoes undergo a process of denudation causing formations hills the rest. Volcanic cones Genuk have bedrock in the form of blocks of lava and volcanic breccias. Denudation process of depositing the material to form soil. The type of soil that developed on volcanic cone Genuk is regosol litosol brown and red. Land on the cliffs and slopes are generally thin, while the basins and river valleys thicker.

Gunung Celering Nature Reserve area had once been encroached upon by local people. Activity encroachment caused damage of primary forests in volcanic cone Genuk. Residents of illegal logging and land conversion from forest to agriculture. Encroachment activities have been banned and strictly regulated since 2010. Nature Reserve Mount Celering currently being rehabilitated to restore the condition and function of the area. Rehabilitation includes rehabilitation in the form of planting several species of trees in rehabilitation and regeneration of natural meaning was not given any treatment of the land rehabilitated. Land rehabilitation also involves the participation of local residents. Rehabilitation efbastions have not reached the maximum results caused by factors such as lack of maintenance, the conditions of land flooded when it rains (the former area of rice fields), and also the speed of grasses and undergrowth dominate and shut down of trees planted. The types grown in the area of rehabilitation, among others sepatudea (Spathodea campanulata), walnut (Aleurites moluccana), kedawung (Parkia roxburghii), kedondong (Spondias pinnata), mindi (Melia azedarach) and bendo (Artocarpus Elastica). Volcanic Cone of Genuk that is not the nature reserve part is still used as fields and plantations. Fields used for crops and cassava (Manihot uttilissima). Developed plantation species are coffee (Coffea arabica).

\section{7)Residual Hill}

The rest of the hill is a form of hills that are still standing after a strong erosion process. Northern Muria Peninsulathere are three hills the rest, namely Bukit Ragas, Bako, and Triwulu. The remainder of the hill located in the east Volcano Genuk. Notching the rest of the hill is very clear as it appeared in the middle of the plains. Rock on the hill residual material in the form of feldspar. The third formation of the rest of the hill, the hill the rest had been in the mine, namely Bukit Ragasa. Feldspar rock is mined for use as raw material for ceramics. Feldspar mining activity has been ongoing since 1995 . This has reduced the activity pernambangan half Bukit Ragas and cause scars in the form of stagnant water basins. While two others are still forested hills. Forest types in the hills the rest of the mixed forest. Fauna that exist in the rest of the hill is still forested, such as birds, snakes, insects, and others.

\section{8)Fluvio-volcanic plains}

Landscape ecology unit fluvio-volcanic plateau is a unit of landscape ecology that bentuklahannya influenced by fluvial and volcanic processes. This form of plateau formation with the choppy surface configuration, especially in areas close to the river valley. Rock material on landscape ecology unit is derived from Muria volcano, which is tuff, lava and sandy tuff. Soil formed is litosol red soil is not very fertile. Fertile soil near streams. The flow of rivers that flow in units of landscape ecology is the Pojok river, Gelis, Wangkong, and Telon. The flow of the river is used as a source of irrigation water.

Landscape ecology unit fluvio-volcanic plains to a concentration of settlements. Administrative center of the Keling and Donorojo Subdistrict and economic centers located in this landscape ecology unit. This is because the surface is relatively flat configuration, access roads, and supported land and water resources is good. Units of land use on landscape ecology fluvio- 
volcanic plateau among other settlements, irrigated rice, rainfed, plantations, fields, and forests. The settlements are scattered with major concentrations in Kelet. The most predominant land use is fields and plantations. Commodities that are developed are rubber plantations (Hevea brasiliensis). Rubber plantations are on land with a surface configuration choppy and not very fertile. Irrigated fields located in river valleys and teraliri irrigation water from the river.

\section{9)Foot Plain of Muria Volcano}

Unit plains landscape ecology foot volcano is part of the Muria volcano. Rock constituent units of the ecology of this landscape is the result of Muria Volcano eruption, namely tuff and lava. The type of soil that is formed is regosol andosol chocolate and cocoa. Muria volcano foot plains have relatively fertile land and water resources are quite good. Therefore, this bentaglahan ecological units are used as agricultural land and plantations, such as rice, coffee, cloves, and kapok.

\section{0)Slope Volcano Muria}

Unit slopes of volcanic landscape ecology is a part of the body Muria volcano. Rock constituent units of the ecology of this landscape is the result of Muria Volcano eruption, namely tuff and lava. This landscape ecology unit has the configuration of a hilly surface. Is the dominant geomorphological processes of erosion and the movement of the rock mass. The geomorphological processes generate river valleys deep. The dominant land use, among others, plantations and rainfed. Types of commodities that developed include coffee, kapok, clove and chocolate. Coffee much developed, especially in the village of Damarwulan. Plantation is located on the slopes of the hills, while rainfed located in the river valley. Agricultural commodities developed in paddy fields was upland rice and pulses. Muria volcano on the slopes there is also a hardwood forest produce which can be used as raw material for building and industrial carving.

\section{1)Caldera Volcano Muria}

Muria Volcano is a strato volcano. Muria active volcanoes is estimated at $0.8 \mathrm{Ma}$ to about $0.32 \mathrm{Ma}$. Muria volcano eruptions in the past left a mark in the form of the caldera. The walls of the caldera Muria volcano has now terdenudasi powerful that leave scars in the form of hills with blocks of lava rock. The hills are a rock is more resistant than the surrounding material. Currently eroded caldera wall, easily weathered rocks will be eroded in advance and leaving a resistant rock. The highest peak in Muria volcano is Songolikur peak or Saptorenggo peaks with an altitude of 1602 above sea level.

The rock material in the caldera Muria volcano is lava blocks. Block lava-lava blocks muria the caldera has been eroded into a valley of rocks in a smaller size, both in the size of sand, gravel, gravel, and boulders.
In the valley of the caldera was formed soil in the form of brown latosol soil with high fertility rates. Caldera valley is a basin that holds water flows from springs in the surrounding hills. The water flow into the river Gelis joined with the direction of the flow to the Northeast.

Muria volcano caldera has been inhabited by humans for hundreds of years. Evidence of past civilizations in Muria volcano caldera is the Temple of the Wind and the Temple Bubrah. Both temples are thought to be a place of worship built in the kingdom of Kalinga. The current wind conditions temple and temple ruins Bubrah form an array of blocks of rock. This society still mengkeramatkan the temple. Forms pengkeramatannya is the ritual and abstinence for those who will visit the temple. Existing settlements in the valley Muria volcano caldera is Tempur Village, Keling Subdistrict. Tempurs villagers mostly work as farmers. Agricultural land in the village of combat may be grouped into irrigated rice in paddy fields which can Gelis river flowing water, rainfed areas, moor and plantation. Paddy fields planted in and sometimes interspersed with crops, fields planted with crops, whereas plantations in the form of a coffee plantation (Coffea arabica). Tempur Coffee is one of the flagship products of the Tempur village. Tempur village is a tourist village. Tempur village is also a gateway to climb to the summit of Songolikur, Angin Temple and Bubrah Temple. It aims to maintain the existence of cultural sites, the environment, and improve the welfare of society.

\section{Conclusion}

Northern Muria Peninsula is a complex territory. Landscape in this region is strongly influenced by volcanism in the past of Muria Volcano and Genuk Volcano and present geomorphological processes such as fluvial and marine. Potential resources in the northern Muria Peninsula such as marine, mining, agriculture, farming, and tourism. Marine resource potential located in shallow waters in the form of marine fishery products. Mining potential in the form of iron sand, feldspar rock and stone. Agricultural potential in the form of rice, cassava and aquaculture of the pond. Potential of plantations such as rubber, coffee, kapok, cloves and brown. Tourism potential in the form of places that can be developed into a mainstay tourist attractions, such as Tritip cave, the Portuguese bastion, Mandalika Island, Tempur Tourism Village, Angin Temple, Bubrah Temple, and climb route to the Songolikur Summit. Muria Peninsula area management should be tailored to the potential and function of each area so as not to cause damage to the environment.

\section{References}

Badan Konservasi Sumberdaya Alam Jawa Tengah. (2009). Statistik Balai KSDA Jawa Tengah Tahun 2008. Semarang: BKSDA Jateng. 
Dikou, A., Papapanagiotou, E., \& Troumbis, A. (2011) Integrating Landscape Ecology and Geoinformatics to Decipher Landscape Dynamics for Regional Planning. Environmental Management. 48, pp.523538.

Fandeli, C., \& Muhammad. (2009). Prinsip-Prinsip Dasar Mengkonservasi Lanskap. Yogyakarta: Gadjah Mada University Press.

Forman, R.T.T., \& Godron, M. (1986). Landscape Ecology. New York: John Wiley and Sons.

Mardiatno, D. (2002). Kajian Geoekologi Daerah Kepesisiran Lombok Barat Untuk Pengembangan Wisata Pantai. Majalah Geografi Indonesia. 60(1), 57-75.

McBirney, A.R., Serva, B., Guerra, M., \& Connor, C.B. (2003).Volcanic and Seismic Hazards at a Proposed Nuclear Power Site in Central Java. Journal of Volcanology and Geothermal Research. 126 (2003) 11-30.

Sultanisah (2007). Pendekatan Geoekologi untuk Kajian Penggunaan Lahan di Sebagian Teluk Palu Provinsi Sulawesi Tengah. Thesis. Universitas Gadjah Mada, Yogyakarta.

Sunarto. (2004). Perubahan Fenomena Geomorfik Daerah Kepesisiran di Sekeliling Gunungapi Muria Jawa Tengah (Kajian Paleogeomorfologi). Disertation. Universitas Gadjah Mada Yogyakarta

Wibowo, B., Suntoko, H., Kironi, B., Hamzah, I., \& Mamay, S. (2008). Analisis Probabilistik dan Deterministik Bahaya Vulkanik Muria Terhadap Tapak PLTN Ula. Prosiding Seminar Nasional Pengembangan Energi Nuklir 2008, ISSN 19791208. 